\title{
Neutronic analysis of a high power density hybrid reactor using innovative coolants
}

\author{
SENAY YALÇIN ${ }^{1}$, MUSTAFA ÜBEYLI ${ }^{2, *}$ and ADEM ACIR ${ }^{3}$ \\ ${ }^{1}$ Bahçeșehir Üniversitesi, Fen-Edebiyat Fakültesi, İstanbul, Turkey \\ ${ }^{2}$ TOBB Ekonomi ve Teknoloji Üniversitesi, Mühendislik Fakültesi, Ankara, \\ Turkey \\ ${ }^{3}$ Gazi Üniversitesi, Teknik Eǧitim Fakültesi, Teknikokullar, Ankara, Turkey \\ e-mail: mubeyli@etu.edu.tr
}

MS received 13 July 2004; revised 23 May 2005

\begin{abstract}
In this study, neutronic investigation of a deuterium-tritium (DT) driven hybrid reactor using ceramic uranium fuels, namely $\mathrm{UC}, \mathrm{UO}_{2}$ or $\mathrm{UN}$ under a high neutron wall load (NWL) of $10 \mathrm{MW} / \mathrm{m}^{2}$ at the first wall is conducted over a period of 24 months for fissile fuel breeding for light water reactors (LWRs). New substances, namely, Flinabe or $\mathrm{Li}_{20} \mathrm{Sn}_{80}$ are used as coolants in the fuel zone to facilitate heat transfer out of the blanket. Natural lithium is also utilized for comparison to these two innovative coolants. Neutron transport calculations are performed on a simple experimental hybrid blanket with cylindrical geometry with the help of the SCALE 4.3 System by solving the Boltzmann transport equation with the XSDRNPM code in 238 neutron groups and an $\mathrm{S}_{8}-\mathrm{P}_{3}$ approximation. The investigated blanket using Flinabe or $\mathrm{Li}_{20} \mathrm{Sn}_{80}$ shows better fissile fuel breeding and fuel enrichment characteristics compared to that with natural lithium which shows that these two innovative coolants can be used in hybrid reactors for higher fissile fuel breeding performance. Furthermore, using a high NWL of $10 \mathrm{MW} / \mathrm{m}^{2}$ at the first wall of the investigated blanket can decrease the time for fuel rods to reach the level for charging in LWRs.
\end{abstract}

Keywords. Fusion; fission; hybrid reactor; fissile fuel breeding

\section{Introduction}

Fusion can serve as an inexhaustible energy source for humankind. Although there have been significant numbers of research and development facilities set up, particularly on magnetic fusion energy (MFE) and inertial fusion energy (IFE), commercial penetration of fusion energy reactors in to the energy market will be probably towards the year 2050. On the other hand, a fusion-fission (hybrid) reactor may have potential for earlier deployment of fusion

${ }^{*}$ For correspondence 
reactors in commercial electricity production due to its distinctive features. A hybrid reactor is a multi-purpose reactor that combines fusion and fission processes. The basic principle in this type of reactor is to convert the fertile materials $\left(\mathrm{U}^{238}\right.$ or $\left.\mathrm{Th}^{232}\right)$, located in the blanket surrounding the fusion plasma, into fissile materials $\left(\mathrm{Pu}^{239}\right.$ or $\left.\mathrm{U}^{233}\right)$ by transmutation through the capture of the high yield fusion neutrons (Berwald et al 1982; Greenspan 1984; Lee et al 1982; Moir 1982; Raghep et al 1979; Şahin \& Al-Kusayer 1985; Şahin et al 1986, 1991a, 1999, 2001, 2003; Şahin \& Yapici 1999; Şahin \& Übeyli 2004; Übeyli 2003; Yapıcıet al 2002, 2003; Yapıc1\& Übeyli 2004). In addition to neutron capture process, they may also undergo a substantial amount of fission under the irradiation by high energetic $14 \mathrm{MeV}-(\mathrm{D}, \mathrm{T})$ neutrons to increase fusion energy. Moreover, a hybrid reactor can burn and/or transmute the nuclear wastes effectively by using very energetic fusion neutrons (Şahin \& Yapıc11989, 1998; Şahin et al 1991, 1994, 2003b; Übeyli 2004).

Presently, the most widely used nuclear reactor for electricity generation is the light water reactor (LWR) that uses low enriched uranium (containing $3-4 \%{ }^{235} \mathrm{U}$ ). Therefore, substantial amounts of enriched fuel are needed for charging in LWRs. By using a fusion-driven hybrid reactor, production of sufficient amounts of enriched fissile fuel for LWRs is possible. Types and properties of fuel, coolant and structural material, blanket configuration and geometrical considerations have paramount importance in designing hybrid reactors to optimize basic neutronic parameters. In order to improve the neutronic performance of the reactor by optimizing these parameters, different selections in blanket design should be investigated.

In previous studies, a neutron wall load of a few $\mathrm{MW} / \mathrm{m}^{2}$ was used for neutronic analysis of hybrid reactor using uranium as nuclear fuel (Şahin et al 1998; Yapıcıet al 1999; Yapıc1 \& Özceyhan 2000). However, in order to get higher neutronic and thermal performance in a fusion or hybrid reactor, higher neutron wall loads (NWLs) will be required. Higher neutron wall loads will also need suitable blanket materials and designs to be handled. There are two ways to reach a high NWL in a fusion reactor:

(1) Use of a protective flowing liquid wall between the plasma and the solid first wall, or

(2) selection of refractory metals or alloys as first wall material.

In the first case, the high neutron flux will be strongly decreased in the protective liquid wall before reaching the first wall. Hence, it will not be effective for fissile fuel breeding in the blanket region. A very extensive and detailed study was done by Abdou and APEX Team on the high power density pure fusion reactor by using refractory metals and alloys as structural material (Abdou 1999). Refractory metals and alloys can withstand much higher NWLs than either conventional austenitic steels or low activation materials (ferritic/martensitic steels, vanadium alloys, $\mathrm{SiC}_{\mathrm{f}} / \mathrm{SiC}$ composite). Therefore, to comply with high NWLs in a fusion reactor, refractory metals or alloys have to be used as structural material. Niobium, tantalum, chromium, molybdenum and tungsten alloys with pure chromium and pure tungsten are considered as potential candidates to get high performance in fusion reactors. Radiation damage and neutronic analysis of a fusion reactor using refractory alloys, namely $\mathrm{W}-5 \mathrm{Re}$, T111 (Ta-8W-2Hf), TZM (Mo alloy) and Nb-1Zr alloys were investigated in a fusion reactor study (Abdou 1999).

This study presents neutronic performance of the new coolants, $\mathrm{LiF} \cdot \mathrm{NaF} \cdot \mathrm{BeF}_{2}$ (Flinabe) and $\mathrm{Li}_{20} \mathrm{Sn}_{80}$ in a (DT) fusion-driven hybrid reactor using different ceramic uranium fuels, namely $\mathrm{UC}, \mathrm{UO}_{2}$ and $\mathrm{UN}$ under a high $\mathrm{NWL}$ of $10 \mathrm{MW} / \mathrm{m}^{2}$ for period of 24 months. For comparison with these coolants, natural lithium also has been investigated. 
Table 1. Properties of liquid tritium breeders.

\begin{tabular}{|c|c|c|c|c|c|}
\hline Property & $\mathrm{Li}$ & $\mathrm{Li}_{17} \mathrm{~Pb}_{83}$ & $\mathrm{Li}_{2} \mathrm{BeF}_{4}$ & $\mathrm{Li}_{20} \mathrm{Sn}_{80}$ & Flinabe \\
\hline Melting point $\left({ }^{\circ} \mathrm{C}\right)$ & 180 & 235 & 459 & 330 & $\sim 300$ \\
\hline Density $\left(\mathrm{g} / \mathrm{cm}^{3}\right)$ & 0.48 & 8.98 & $2 \cdot 0$ & $6 \cdot 2$ & $2 \cdot 0$ \\
\hline Li density $\left(\mathrm{g} / \mathrm{cm}^{3}\right)$ & 0.48 & 0.062 & 0.28 & 0.09 & $0 \cdot 12$ \\
\hline Breeding property & Good & Fairly good & $\begin{array}{l}\text { Neutron } \\
\text { multiplier } \\
\text { required }\end{array}$ & $\begin{array}{l}\text { Neutron } \\
\text { multiplier } \\
\text { required }\end{array}$ & $\begin{array}{l}\text { Neutron } \\
\text { multiplier } \\
\text { required }\end{array}$ \\
\hline Chemical stability & Active & Middle & $\begin{array}{l}\text { Almost } \\
\text { stable }\end{array}$ & $\begin{array}{l}\text { Almost } \\
\text { stable }\end{array}$ & $\begin{array}{l}\text { Almost } \\
\text { stable }\end{array}$ \\
\hline Tritium solubility & High & Very low & Very low & - & - \\
\hline
\end{tabular}

References: Bettis \& Robertson 1970; Grimes \& Cantor 1972; Malinauskas \& Richardson 1974; Smith et al 1985; Moriyama et al 1998, 1995; Sze et al 1999; Youssef et al 2002;

\section{Liquid tritium breeders}

Coolant supplying heat transfer in a fusion reactor must be a lithium-bearing liquid in order to maintain sufficient tritium for the (DT) fusion driver. Primary candidates are the liquid metals lithium, $\mathrm{Li}_{17} \mathrm{~Pb}_{83}$ and LiSn, and the molten salts, Flibe and Flinabe. Some important properties of these candidate tritium breeders are given in table 1 (Bettis \& Robertson 1970; Grimes \& Cantor 1972; Malinauskas \& Richardson 1974; Smith et al 1985; Moriyama et al 1995, 1998; Sze et al 1999; Youssef et al 2002). Lithium, an alkali metal, is one of the primary candidates due to its high tritium breeding ratio, but is very chemically active and reacts violently with air and water (Moriyama et al 1998).

Recently, LiSn and Flinabe have been investigated as innovative tritium breeders and they are found attractive due to their low melting temperatures and low vapour pressures. The vapour pressure of $\mathrm{Sn}$ is several orders of magnitude lower than that of pure lithium. LiSn allows higher operating temperatures than pure lithium due to fact that it has very low vapour pressure. It has been considered a potential new liquid wall coolant especially for handling high wall loads. However, the breeding performance of LiSn is very low compared to that of pure $\mathrm{Li}$ and $\mathrm{Li}_{17} \mathrm{~Pb}_{83}$, which may require additional multiplier material (Sze et al 1999). Flinabe, like LiSn, is an attractive tritium breeder due to its relatively low melting temperature and low vapour presssure. The melting point of Flinabe is $\sim 300^{\circ} \mathrm{C}$ (Grimes \& Cantor 1972). However, it has poor tritium breeding potential and activation of sodium in the fusion environment is a concern (Youssef et al 2002).

\section{Blanket structure}

The neutronic calculations are conducted for previously introduced experimental hybrid blanket geometry (Şahin et al 1986). This blanket was evaluated as a basic and simple structure for the purpose of assessment of the main engineering performance of fusion-fission (hybrid) reactors in a series of generic studies (Şahin et al 1991a, 1998, 1999, 2001; Şahin \& Ya1c11999; Übeyli 2003). A side view of the blanket is shown in figure 1 .

Table 2 gives the composition and density of the materials in the blanket. The first wall and the cladding of the fuel rods are made of W-5Re to handle high NWL and helium at $40 \mathrm{~atm}$ is used as a coolant in the first wall. The first wall separates the fuel zone from the fusion 


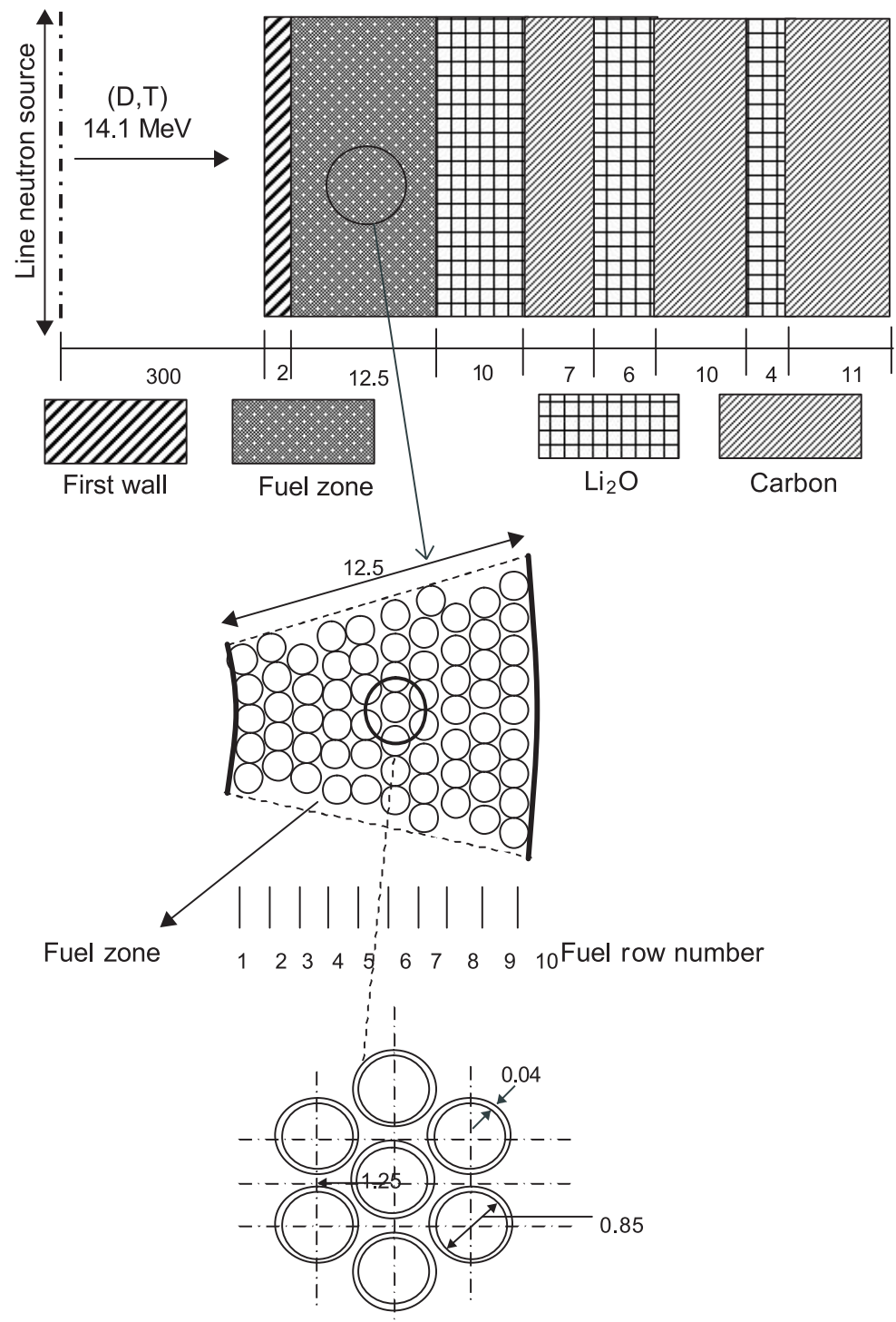

Figure 1. Cross-sectional view of the investigated blanket (dimensions in $\mathrm{cm}$ ).

plasma chamber. The latter has a zone thickness of $12.5 \mathrm{~cm}$ which is made up of $\mathrm{UC}, \mathrm{UO}_{2}$ or $\mathrm{UN}$ as nuclear fuel, natural lithium, Flinabe or $\mathrm{Li}_{20} \mathrm{Sn}_{80}$ as coolant to transfer heat and $\mathrm{W}-5 \mathrm{Re}$ as clad for the fuel rods. $V_{\text {moderator }} / V_{\text {fuel }}$ is chosen as 2 and the fuel rods are located in hexagonal geometry with ten rows of pitch length $1.25 \mathrm{~cm}$ in the radial direction.

In the investigated blanket, selection of the potential structural materials for a high power density reactor is conducted on the basis of the following considerations.

Among the candidate structural materials for fusion reactors, tungsten (W) has the highest operating temperature limit $\left(1500^{\circ} \mathrm{C}\right)$. The NWL limit of $\mathrm{W}$ strongly depends on the temperature at the interface between the wall and the coolant. W can withstand a neutron wall 
Table 2. Atomic densities of the blanket materials.

\begin{tabular}{|c|c|c|c|}
\hline Zone name & Material & Nuclides & Atomic density $\left(10^{24} / \mathrm{cm}^{3}\right)$ \\
\hline First wall & $\begin{array}{c}\text { Helium }(80 \%) \\
\text { W-5Re alloy }(20 \%)\end{array}$ & $\begin{array}{l}\mathrm{He} \\
\mathrm{W} \\
\mathrm{Re}\end{array}$ & $\begin{array}{l}8.66980 \times 10^{-4} \\
1.19960 \times 10^{-2} \\
3.15700 \times 10^{-4}\end{array}$ \\
\hline \multirow[t]{7}{*}{ Fuel zone } & $\mathrm{UC}(31 \cdot 3 \%)$ & ${ }^{235} \mathrm{U}$ & $\begin{array}{l}7.33610 \times 10^{-5} \\
1.02007 \times 10^{-2} \\
1.02747 \times 10^{-2}\end{array}$ \\
\hline & $\mathrm{UO}_{2}(31 \cdot 3 \%)$ & $\begin{array}{l}{ }^{C}{ }^{23} \mathrm{U} \\
{ }^{238} \mathrm{U}\end{array}$ & $\begin{array}{l}1.02747 \times 10^{-2} \\
5.46240 \times 10^{-5} \\
7.59541 \times 10^{-3}\end{array}$ \\
\hline & $\mathrm{UN}(31 \cdot 3 \%)$ & $\begin{array}{c}{ }^{\mathrm{O}} \\
{ }^{235} \mathrm{U} \\
{ }^{238} \mathrm{U} \\
\mathrm{N}\end{array}$ & $\begin{array}{l}1.53010 \times 10^{-2} \\
7.64770 \times 10^{-5} \\
1.06340 \times 10^{-2} \\
1.07111 \times 10^{-2}\end{array}$ \\
\hline & Natural lithium $(62 \cdot 6 \%)$ & $\begin{array}{l}{ }^{6} \mathrm{Li} \\
{ }^{7} \mathrm{Li}\end{array}$ & $\begin{array}{l}2.17530 \times 10^{-3} \\
2.68280 \times 10^{-2}\end{array}$ \\
\hline & Flinabe $(62.6 \%)$ & $\begin{array}{c}\mathrm{Na} \\
\mathrm{Be} \\
\mathrm{F} \\
{ }^{6} \mathrm{Li} \\
{ }^{7} \mathrm{Li}\end{array}$ & $\begin{array}{l}6.55672 \times 10^{-3} \\
6.55672 \times 10^{-3} \\
2.62268 \times 10^{-2} \\
4.91754 \times 10^{-4} \\
6.06496 \times 10^{-3}\end{array}$ \\
\hline & $\mathrm{Li}_{20} \mathrm{Sn}_{80}(62 \cdot 6 \%)$ & $\begin{array}{l}\mathrm{Sn} \\
{ }^{6} \mathrm{Li} \\
{ }^{7} \mathrm{Li}\end{array}$ & $\begin{array}{l}1.94115 \times 10^{-2} \\
3.63965 \times 10^{-4} \\
4.48890 \times 10^{-3}\end{array}$ \\
\hline & W-5Re alloy $(6 \cdot 1 \%)$ & $\begin{array}{l}\mathrm{W} \\
\mathrm{Re}\end{array}$ & $\begin{array}{l}3.65880 \times 10^{-3} \\
1.92580 \times 10^{-4}\end{array}$ \\
\hline $\begin{array}{l}\text { Tritium } \\
\text { breeding zone }\end{array}$ & $\mathrm{Li}_{2} \mathrm{O}(100 \%)$ & $\begin{array}{l}{ }^{6} \mathrm{Li} \\
{ }^{7} \mathrm{Li} \\
\mathrm{Al} \\
\mathrm{O}\end{array}$ & $\begin{array}{l}4.63800 \times 10^{-3} \\
5 \cdot 70740 \times 10^{-2} \\
3 \cdot 01400 \times 10^{-3} \\
3.08400 \times 10^{-2}\end{array}$ \\
\hline Reflector & Carbon $(100 \%)$ & $\mathrm{C}$ & $1.12800 \times 10^{-1}$ \\
\hline
\end{tabular}

load of $10 \mathrm{MW} / \mathrm{m}^{2}$ for an interface temperature of $750^{\circ} \mathrm{C}$ between the wall and the coolant. Detailed information and graphics on the wall load limits of different structural materials can be found (Abdou 1999). W has very high thermal conductivity (145 W/mK at room temperature (RT)) and very low thermal expansion coefficient $\left(4 \cdot 5 \times 10^{-6} / \mathrm{K}\right)($ Smid et al 1998). Rhenium additions to pure tungsten improve creep strength, recrystallization resistance and ductility even at lower temperatures. More than $30 \%$ of rhenium can be substitutionally built in the tungsten lattice. Alloy W-5\% Re, a single phase material, still has fairly high thermal conductivity, compared to rhenium-free tungsten alloys, excellent thermal shock resistance, and high strength and good braze capability, as well as some weldability. Furthermore, workability and machinability of $\mathrm{W}-5 \mathrm{Re}$ even at room temperature are adequate for the size and shape of high heat flux armour in plasma-interactive components. In addition, compatibility of tungsten and its alloys with different coolants even at high temperatures is very good. Pure tungsten and tungsten alloys are generally compatible with lithium up to $1370^{\circ} \mathrm{C}$. Tungsten also has good compatibility with $\mathrm{Li}_{17} \mathrm{~Pb}_{83}$, at temperatures $>600^{\circ} \mathrm{C}$. There is no reliable data 
about the compatibility of $\mathrm{W}$ and $\mathrm{W}$ alloys with other candidate coolants for fusion reactors, such as Li-Sn, Flinabe and Flibe (Zinkle \& Ghoniem 2000).

Regions behind the fuel zone forms a sandwich structure consisting of three $\mathrm{Li}_{2} \mathrm{O}$ zones and three carbon zones. These zones are used to enhance the tritium breeding in the blanket and to reduce neutron leakage out of the blanket as shown in figure $1 . \mathrm{Li}_{2} \mathrm{O}$ is the most important solid tritium breeder that has high tritium breeding potential, low vapour pressure even at a high temperature, low activation and high lithium density. Carbon, a very common reflector material, is chosen to use in the blanket because of its good reflectivity property.

\section{Calculational tools}

Numeric calculations are based on the one-dimensional cylindrical model. Neutron transport calculations are performed with the help of the SCALE4.3 system by solving the Boltzmann transport equation with the XSDRNPM code (Greene \& Petrie 1997) in a $\mathrm{S}_{8}-\mathrm{P}_{3}$ approximation with Gaussian quadratures (Şahin 1991) using the 238-group library, derived from ENDF/BV (Jordon \& Bowman 1997). And the resonance calculations in the fissionable fuel element cell are performed with

- BONAMI (Greene 1997) for unresolved resonances and

- NITAWL-II (Greene et al 1997) for resolved resonances.

CSAS control module (Landers \& Petrie 1997) is used to produce the resonance self-shielded weighted cross-sections for XSDRNPM.

\section{Numerical results}

In order to evaluate the neutronic performance of a (DT) fusion neutron driven hybrid reactor, the main parameters, namely tritium breeding ratio (TBR), energy multiplication factor and fissile fuel breeding capability, have to be determined. In the following sections these parameters as well as the safeguard aspects of plutonium isotopes for this study are explained.

\subsection{Tritium breeding ratio}

Tritium, an artificial fusile fuel, can be extracted from the nuclear reactions of ${ }^{6} \mathrm{Li}(n, \alpha) \mathrm{T}$ and ${ }^{7} \mathrm{Li}\left(n, n^{\prime} \alpha\right) \mathrm{T}$. The tritium breeding reactions of ${ }^{6} \mathrm{Li}$ and ${ }^{7} \mathrm{Li}$ isotopes are as follows:

$$
\begin{aligned}
& { }^{6} \mathrm{Li}+n \longrightarrow \alpha+\mathrm{T}+4.784(\mathrm{MeV}), \\
& { }^{7} \mathrm{Li}+n \longrightarrow \alpha+\mathrm{T}+n-2.467(\mathrm{MeV}) .
\end{aligned}
$$

Therefore, sufficient tritium production from the lithium bearing coolants in the blanket is of primary concern for (DT) driven hybrid reactors. Overall TBR must be greater than 1.05 to maintain the self-sufficiency of the (DT) driver. Figure 2 illustrates total TBR gained from the liquid breeder in the fuel zone. $\mathrm{Li}_{2} \mathrm{O}$ zones change with respect to a period of operation of 24 months for 3 different coolants with 3 different fuels. The highest TBR values are reached when natural lithium is used as coolant as expected due to its higher Li atomic density compared to the other two coolants. Although Flinabe has slightly higher Li atomic density than $\mathrm{Li}_{20} \mathrm{Sn}_{80}$ (see table 2) it contains $\mathrm{F}$ deteriorating neutron economy due to its high neutron 


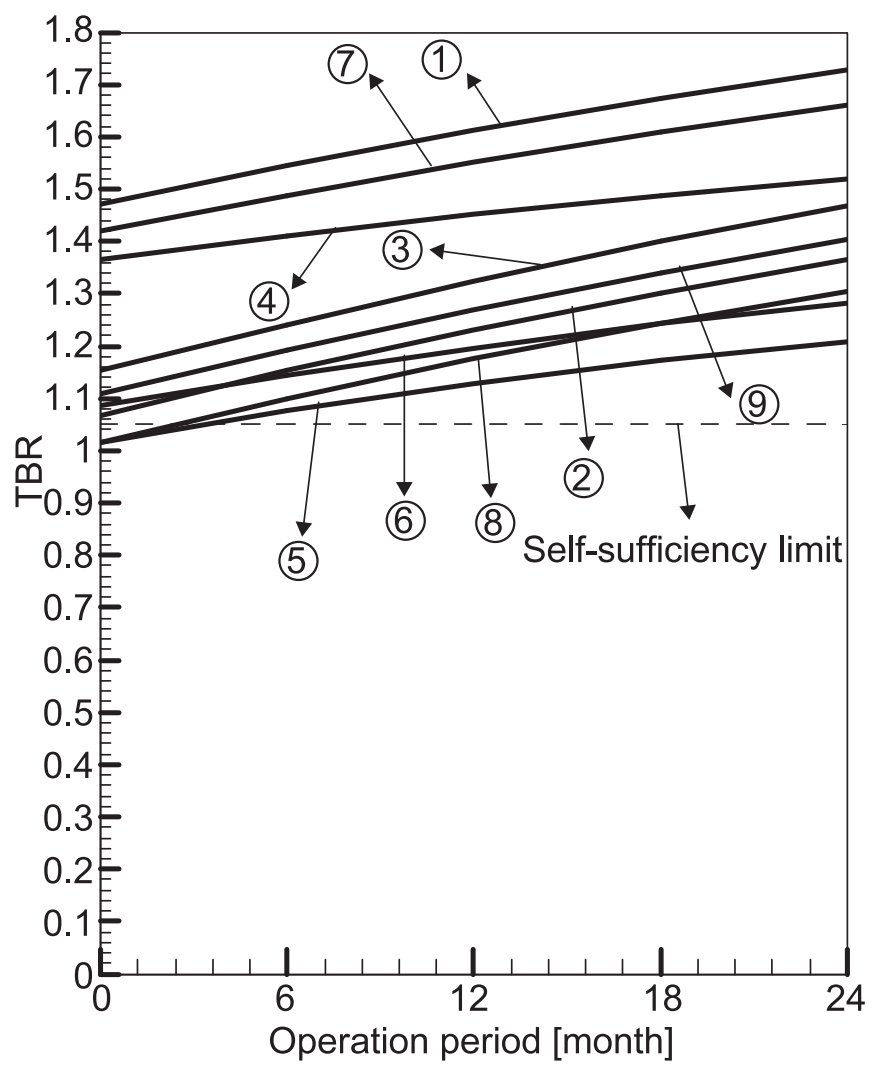

Figure 2. TBR variation during operation period for: UC fuel with (1) natural lithium; (2) Flinabe; (3) $\mathrm{Li}_{20} \mathrm{Sn}_{80} ; \mathrm{UO}_{2}$ fuel with (4) natural lithium; (5) Flinabe; (6) $\mathrm{Li}_{20} \mathrm{Sn}_{80}$; UN fuel with (7) natural lithium; (8) Flinabe; (9) $\mathrm{Li}_{20} \mathrm{Sn}_{80}$.

absorption cross-section. Therefore, the blanket with Flinabe has lower TBR values than that with $\mathrm{Li}_{20} \mathrm{Sn}_{80}$.

At starting in all cases, TBR is obtained in values greater than 1.05 except for the Flinabe with $\mathrm{UN}$ or $\mathrm{UO}_{2}$ reaching a TBR value of 1.05 after a very short operation time ( $\sim 3$ months). Among the fuels, the best performance with respect to TBR is found for UC, followed by UN and $\mathrm{UO}_{2}$. All TBR values increase gradually with operation time due to the fact that fissile fuel accumulation in the blanket causes neutron multiplication by fissioning.

\subsection{Energy multiplication}

In the blanket, exothermic reactions, namely fission and neutron capture in ${ }^{6} \mathrm{Li}$ cause the multiplication of the incident fusion neutron energy. Energy multiplication (M) in the investigated blanket is increased mainly by the fission reactions of fuel, so that a significant quantity of electricity can be produced in situ. Hence, the more the occurrence of the fission reaction in the blanket, the greater is the generation energy multiplication. $M$ can be defined as follows:

$$
M=\frac{200 *\left\langle\Phi \bullet \Sigma_{f}\right\rangle+4.784 * T_{6}-2.467 * T_{7}}{14.1}+1,
$$


$\left\langle\Phi \bullet \Sigma_{f}\right\rangle=\iint \Phi \bullet \Sigma_{f} \mathrm{~d} E \mathrm{~d} V:$ Total integral fission rate

$T_{6}=\left\langle\Phi \bullet \Sigma_{(n, \alpha) T}\right\rangle$ on ${ }^{6} \mathrm{Li}$,

$T_{7}=\left\langle\Phi \bullet \Sigma_{\left(n, n^{\prime} \alpha\right) T}\right\rangle$ on ${ }^{7} \mathrm{Li}$.

The heat from the gamma generated is ignored in the calculation of $M$, as it is relatively very small compared to heat gained from fission. Figure 3 depicts the $M$ variation versus operation time. One can see clearly from this figure that UC and UN have similar $M$ values whereas $\mathrm{UO}_{2}$ has fairly low $M$ values compared to the other two fuels, owing to its lower $U$ content compared to UC and UN. $M$ increases with time for all case because more fission reaction occurs with time due to accumulation of fissile isotopes (mainly ${ }^{239} \mathrm{Pu}$ ) in the blanket. Depending on the coolant type, for UC and UN, $M$ values start in the range of 4-4.6 and reach 7.3-8.3 at the end of the operation period, while for $\mathrm{UO}_{2}$ startup is in the range of 3.43.7 at and increases up to $7 \cdot 3-8 \cdot 3$ at the end of the operation period. $M$ values are obtained in descending order for the blanket using Flinabe, $\mathrm{Li}_{20} \mathrm{Sn}_{80}$ and natural lithium, since natural lithium has higher neutron absorption than either Flinabe or $\mathrm{Li}_{20} \mathrm{Sn}_{80}$ due its much higher $\mathrm{Li}$ atomic density. Therefore, in the blanket with natural lithium, more neutrons are captured by lithium atoms for tritium production than that with either Flinabe or $\mathrm{Li}_{20} \mathrm{Sn}_{80}$. This decreases

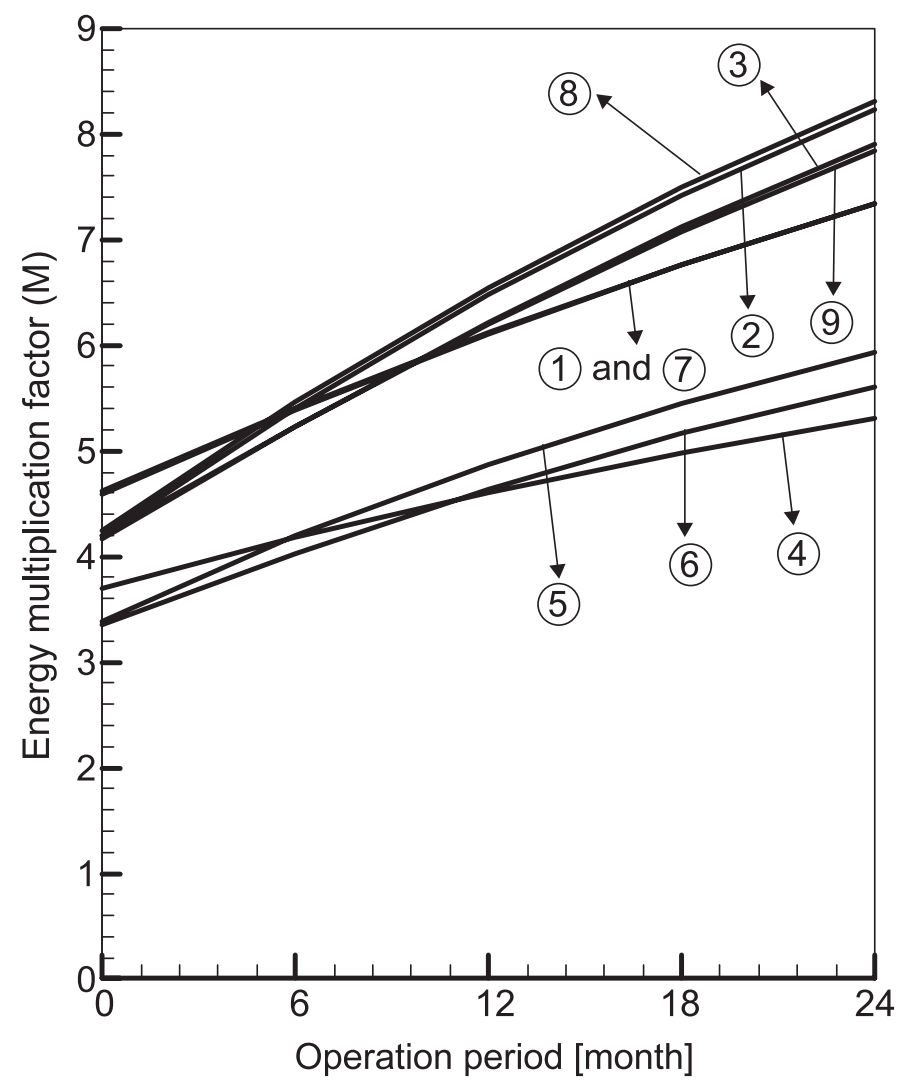

Figure 3. Temporal variation of the energy multiplication for the investigated blanket (legend as in figure 2). 
neutron flux for fission in the fuel zone and therefore energy multiplication in the blanket when natural lithium is used as coolant.

\subsection{Fissile fuel breeding}

The temporal change of the atomic densities of the fissionable fuel components during hybrid reactor plant operation is evaluated at discrete time intervals $\Delta t$ under consideration of the nuclear reactions and radioactive transformation processes.

For breeding reactions:

$$
+\Delta N_{2}=\mathrm{PF} \cdot \Delta t \cdot N_{1} \int \sigma_{b 1}(E) \cdot \Phi(E) \cdot \mathrm{d} E+\Delta t \cdot \lambda_{b 1} \cdot N_{1},
$$

Indices 1 and 2 show mother and daughter isotopes respectively.

For depletion reactions:

$$
+\Delta N=\mathrm{PF} \cdot \Delta t \cdot N \cdot \int \sigma_{\mathrm{dep}}(E) \cdot \Phi(E) \cdot \mathrm{d} E+\Delta t \cdot \lambda \cdot N,
$$

where;

$$
\begin{aligned}
& \Delta N=\text { atomic density change } \\
& \mathrm{PF}=\text { plant factor } \\
& N=\text { atomic density }
\end{aligned}
$$

\begin{tabular}{|c|c|c|c|c|c|c|c|c|c|}
\hline \multirow{3}{*}{$\begin{array}{l}\text { Time } \\
\text { (month) }\end{array}$} & \multicolumn{9}{|c|}{ Fuel coolant } \\
\hline & \multicolumn{3}{|c|}{ Natural lithium } & \multirow[b]{2}{*}{1} & \multirow{2}{*}{$\frac{\text { Flinabe }}{5}$} & \multirow[b]{2}{*}{10} & \multirow[b]{2}{*}{1} & \multirow{2}{*}{$\frac{\mathrm{Li}_{20} \mathrm{Sn}_{80}}{5}$} & \multirow[b]{2}{*}{10} \\
\hline & 1 & 5 & 10 & & & & & & \\
\hline \multicolumn{10}{|l|}{$\mathrm{UC}$} \\
\hline 0.0 & 0.7140 & 0.7140 & 0.7140 & 0.7140 & 0.7140 & 0.7140 & 0.7140 & 0.7140 & 0.7140 \\
\hline $6 \cdot 0$ & $2 \cdot 1854$ & $2 \cdot 1288$ & 2.0227 & 2.7525 & 2.6231 & $2 \cdot 1050$ & 2.4585 & $2 \cdot 3423$ & $2 \cdot 1303$ \\
\hline $12 \cdot 0$ & 3.4405 & $3 \cdot 3580$ & $3 \cdot 1801$ & $4 \cdot 3986$ & $4 \cdot 1934$ & $3 \cdot 3376$ & 3.9013 & 3.7373 & $3 \cdot 3925$ \\
\hline $18 \cdot 0$ & 4.5079 & 4.4210 & $4 \cdot 1972$ & 5.7350 & 5.4902 & 4.4201 & $5 \cdot 0870$ & 4.9214 & 4.5040 \\
\hline $24 \cdot 0$ & 5.4128 & $5 \cdot 3358$ & 5.0857 & 6.8217 & $6 \cdot 5602$ & $5 \cdot 3628$ & 6.0552 & 5.9164 & $5 \cdot 4715$ \\
\hline \multicolumn{10}{|l|}{$\mathrm{UO}_{2}$} \\
\hline 0.0 & 0.7140 & 0.7140 & 0.7140 & 0.7140 & 0.7140 & 0.7140 & 0.7140 & 0.7140 & 0.7140 \\
\hline $6 \cdot 0$ & $2 \cdot 0881$ & $2 \cdot 0398$ & 1.9483 & 2.6904 & 2.5824 & $2 \cdot 0886$ & $2 \cdot 3841$ & $2 \cdot 2803$ & 2.0837 \\
\hline $12 \cdot 0$ & $3 \cdot 2633$ & $3 \cdot 1930$ & 3.0389 & 4.2768 & $4 \cdot 1052$ & 3.2908 & 3.7642 & 3.6172 & $3 \cdot 2954$ \\
\hline $18 \cdot 0$ & $4 \cdot 2683$ & $4 \cdot 1944$ & 3.9997 & $5 \cdot 5625$ & $5 \cdot 3567$ & $4 \cdot 3377$ & 4.9028 & 4.7531 & $4 \cdot 3599$ \\
\hline $24 \cdot 0$ & $5 \cdot 1275$ & $5 \cdot 0627$ & 4.8439 & $6 \cdot 6110$ & $6 \cdot 3895$ & $5 \cdot 2461$ & $5 \cdot 8403$ & $5 \cdot 7138$ & $5 \cdot 2887$ \\
\hline \multicolumn{10}{|l|}{ UN } \\
\hline 0.0 & 0.7140 & 0.7140 & 0.7140 & 0.7140 & 0.7140 & 0.7140 & 0.7140 & 0.7140 & 0.7140 \\
\hline $6 \cdot 0$ & $2 \cdot 1338$ & $2 \cdot 0823$ & 1.9926 & 2.7154 & 2.5948 & 2.0703 & $2 \cdot 3840$ & $2 \cdot 2749$ & 2.0874 \\
\hline $12 \cdot 0$ & $3 \cdot 3490$ & $3 \cdot 2746$ & $3 \cdot 1266$ & 4.3337 & $4 \cdot 1408$ & $3 \cdot 2787$ & 3.7710 & 3.6166 & $3 \cdot 3145$ \\
\hline 18.0 & 4.3865 & $4 \cdot 3096$ & $4 \cdot 1265$ & 5.6509 & 5.4191 & 4.3455 & 4.9166 & 4.7606 & $4 \cdot 3988$ \\
\hline $24 \cdot 0$ & $5 \cdot 2697$ & $5 \cdot 2039$ & 5.0031 & 6.7251 & 6.4762 & $5 \cdot 2793$ & 5.8573 & 5.7271 & $5 \cdot 3466$ \\
\hline
\end{tabular}

Table 3. Temporal CFFE values [wt\%] in the investigated blanket with different coolants.

Numbers below coolant names refer to the row numbers 
$\Delta t=$ time period,

$\lambda=$ radioactive decay constant,

$\Phi=$ neutron flux.

Equations (4) and (5) consider the variations of the number densities of the atoms of the fissionable nuclides by nuclear transmutations and radioactive decay. For fissile fuel breeding calculation, NWL at the first wall is assumed to be $10 \mathrm{MW} / \mathrm{m}^{2}$, corresponding to the power levels in a high power density fusion reactor. Transmutation reactions cause the increase in the fissile fuel content of the fuel (mainly through ${ }^{238} \mathrm{U}(n, \gamma){ }^{239} \mathrm{Pu}$ reaction) during the operation. A total enrichment grade, called the cumulative fissile fuel enrichment (CFFE) is the sum of the isotopic percentages of the pertinent fissile isotopes, such as CFFE $={ }^{235} \mathrm{U}+{ }^{239} \mathrm{Pu}+{ }^{241} \mathrm{Pu}$. Temporal CFFE changes in fuel rows 1, 5 and 10 for the blanket using $\mathrm{UC}, \mathrm{UO}_{2}$ or $\mathrm{UN}$ with coolants natural lithium, Flinabe or $\mathrm{Li}_{20} \mathrm{Sn}_{80}$ are given in table 3. The highest enrichment occurs in the first row due to the availability of the highest neutron flux in this row, as expected. Neutron flux decreases by deeper penetration in the blanket due to elastic or inelastic collisions and reactions with atoms in the fuel zone. In addition, in the fuel zone fission neutrons start to dominate in the neutron spectrum with an average energy of $2 \mathrm{MeV}$. Due to these reasons, the lowest enrichment is observed in row 10.

Among the coolants, highest CFFE values are found for Flinabe, followed by $\mathrm{Li}_{20} \mathrm{Sn}_{80}$ and for natural lithium due to reasons explained in the previous chapter. The blanket using UC

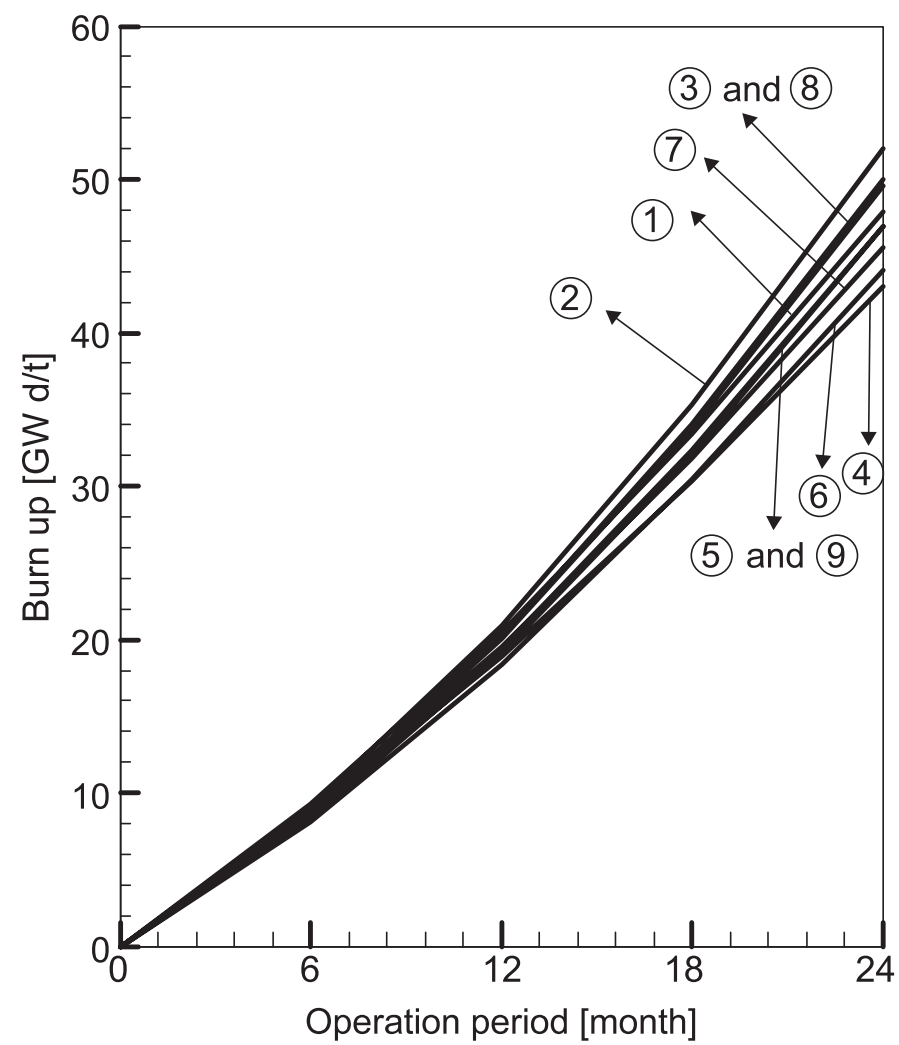

Figure 4. Fissile fuel burnup as a function of operation period (legend as in figure 2). 
or UN has very close enrichment values that one higher than that using $\mathrm{UO}_{2}$. As mentioned before, LWR uses nuclear fuel with fissile fuel enrichment value of $3 \cdot 5-4 \%$. By taking a CFFE value of $3.5 \%$ as reference, at the end of an operation period of 9-15 months, the fuel rods are at a level of charging LWRs depending on the fuel and coolant type and fuel rod position.

Burnup grade of the fuel with respect to operation period for the investigated blanket is shown in figure 4 . When fissile fuel breeding continues in the blanket, burnup of certain parts of the fuel depending on the NWL and neutron flux takes place. As it can be seen from figure 4, burnup increases almost linearly with the operation period for all cases in the blanket. Burning of uranium and plutonium isotopes in the fuel increases plant power but decreases the amount of fissile fuel in the blanket. For LWRs, a burnup limit of $\sim 30.000 \mathrm{MWd} /$ ton is taken into consideration. This limit is reached after an operation period of 16-18 months depending on the coolant and fuel type used in the fuel zone of the blanket.

The net fissile fuel production ability of hybrid reactors for external use in the form of a figure-of-merit (FOM) can be defined as the ratio of the amount of the net ${ }^{239} \mathrm{Pu}$ mass (major fissile isotope) generated to the fission power output of the hybrid blanket. The mathematical formulation of FOM in net ${ }^{239} \mathrm{Pu}(\mathrm{g} / \mathrm{MW}$ year or $\mathrm{kg} / \mathrm{GW}$ year) is described in Şahin (1990) and Şahin et al (1991a) and will not be repeated here. The temporal variation of FOM for the investigated blanket is shown in figure 5. At startup, the highest FOM values in descending

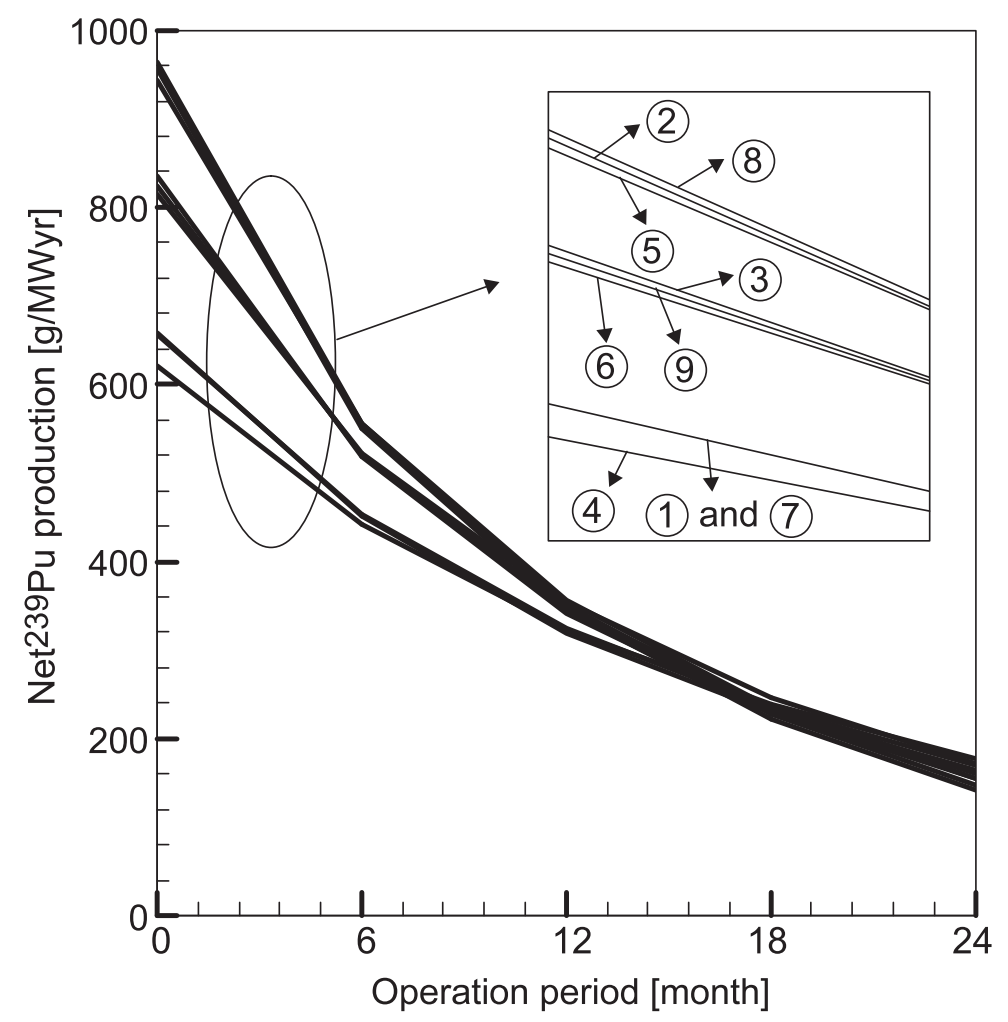

Figure 5. Net ${ }^{239} \mathrm{Pu}$ production in grams per MW fission energy release in the blanket with respect to operation time (legend as in figure 2). 


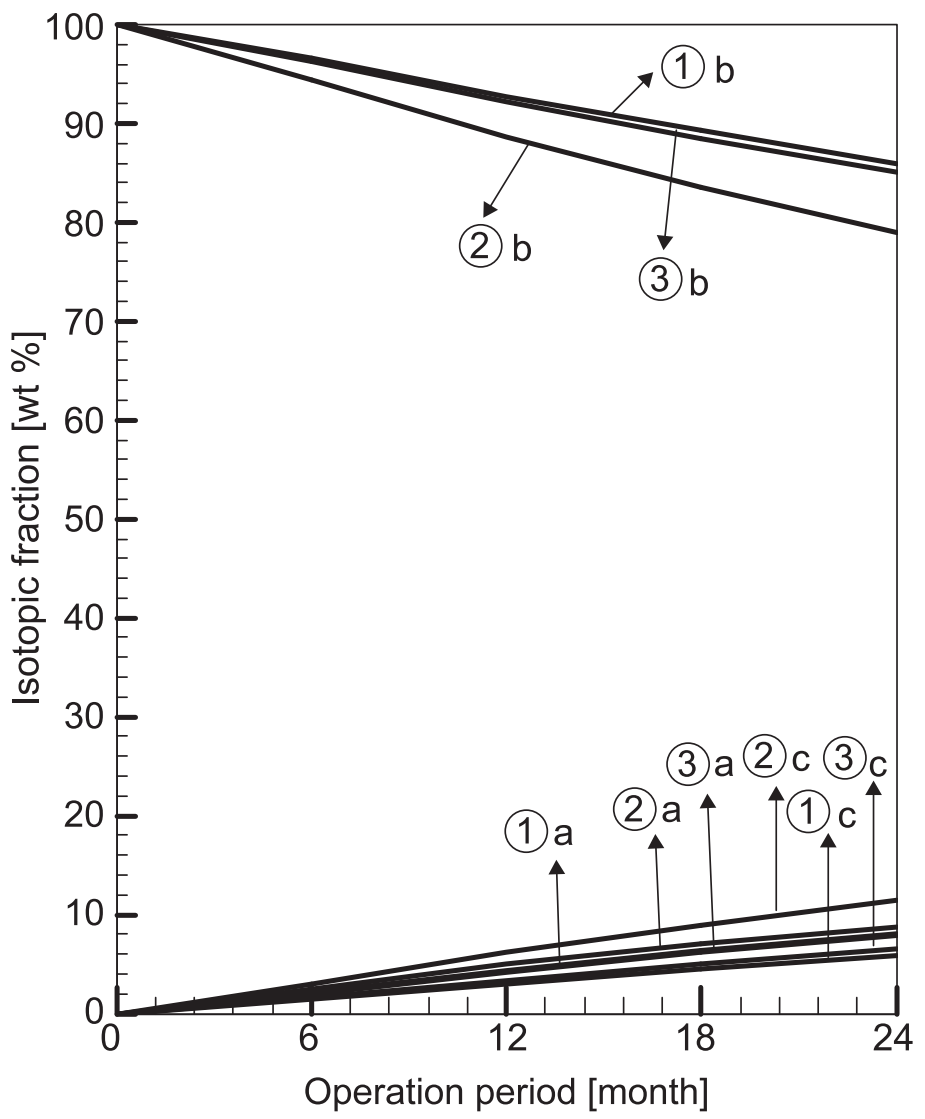

Figure 6. Temporal variation in the percentages of the plutonium isotopes ((a) ${ }^{238} \mathrm{Pu}$; (b) ${ }^{239} \mathrm{Pu}$; (c) ${ }^{240} \mathrm{Pu}$ ) for the fuel UC with (1) natural lithium, (2) Flinabe, (3) $\mathrm{Li}_{20} \mathrm{Sn}_{80}$.

order are observed in the blanket using Flinabe, $\mathrm{Li}_{20} \mathrm{Sn}_{80}$ and natural lithium. FOM values for all three fuels and coolants decrease sharply and become closer with increasing operation period. This means that most of the fissile fuel is burnt in situ and FOM (the excess fuel production) decreases rapidly in the blanket during the period of operation under high neutron load. Even though using high neutron wall load decreases time to reach the desired CFFE value, it greatly increases burnup grades in the blanket.

\subsection{Safeguards aspects of the plutonium component}

Investigation of safeguard aspects of plutonium in a power plant with plutonium breeding potential is very important, since odd isotopes of ${ }^{239} \mathrm{Pu}$ and ${ }^{241} \mathrm{Pu}$ are highly prolific and their isotopic percentages in plutonium must be controlled. Fortunately, the presence of sufficient quantities of even plutonium isotopes, such as ${ }^{238} \mathrm{Pu}$ and ${ }^{240} \mathrm{Pu}$, makes the nuclear fuel reactor grade for commercial utilization. The yield of spontaneous fission neutrons in ${ }^{238} \mathrm{Pu}$ (spontaneous fission half-life of $T_{1 / 2}=5 \times 10^{10}$ years) (Jaeger et al 1968) and ${ }^{240} \mathrm{Pu}\left(T_{1 / 2}=1.2 \times 10^{11}\right.$ years) are about 110,000 and 45,000 times higher than in ${ }^{239} \mathrm{Pu}\left(T_{1 / 2}=5.5 \times 10^{15}\right.$ years $)$ respectively. Hence, only low percentages of ${ }^{238} \mathrm{Pu}$ and $/$ or ${ }^{240} \mathrm{Pu}$ would degrade the generated plutonium and make it useless for military applications, as it would make the explosive yield 


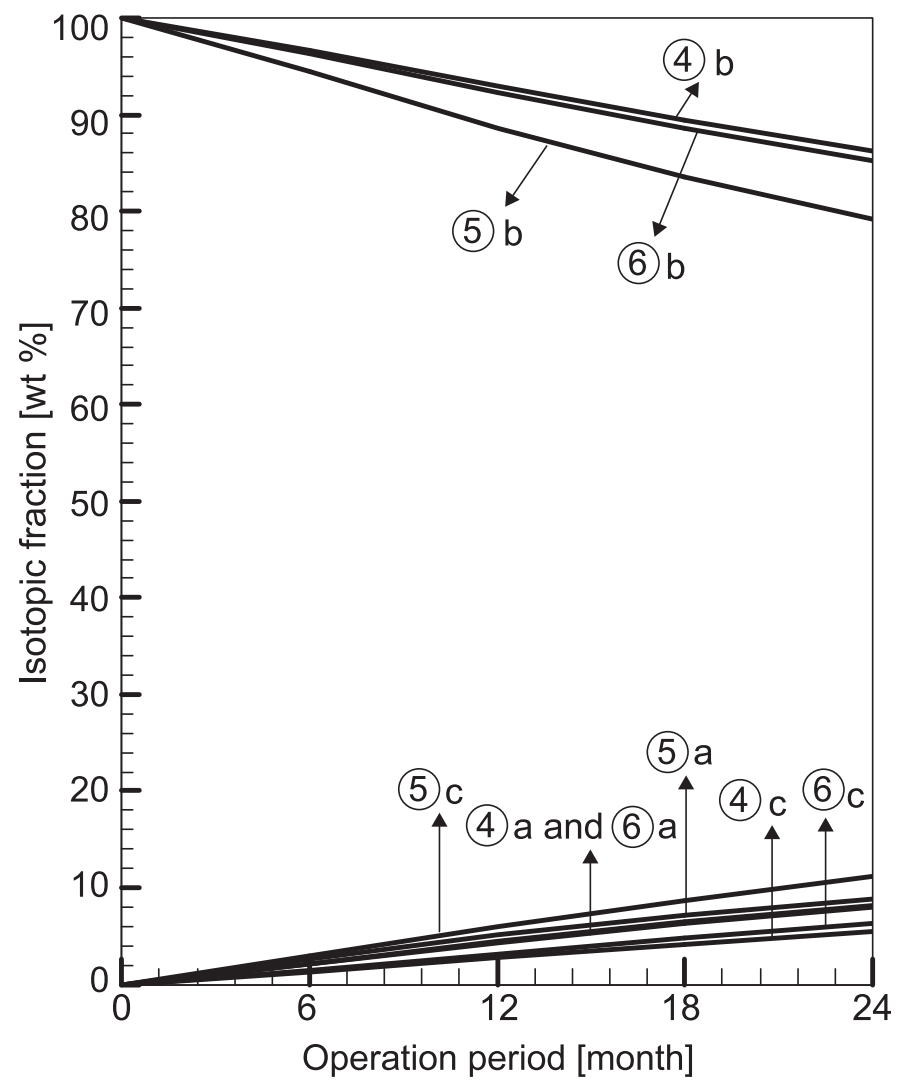

Figure 7. Temporal variation in the percentages of the plutonium isotopes ((a) ${ }^{238} \mathrm{Pu}$; (b) ${ }^{239} \mathrm{Pu}$; (c) ${ }^{240} \mathrm{Pu}$ ) for the fuel $\mathrm{UO}_{2}$ with (4) natural lithium, (5) Flinabe, (6) $\mathrm{Li}_{20} \mathrm{Sn}_{80}$.

of the nuclear device unpredictable (Meyer et al 1977). Earlier study indicated that the ${ }^{240} \mathrm{Pu}$ content in weapon grade plutonium fuel must be kept below 5\% to avoid undesired supercritical pre-ignition before the compression of the plutonium component can be accomplished according to the design criteria of the nuclear device (Şahin \& Ligou 1980, 1982; Şahin 1980). Therefore, ${ }^{238} \mathrm{Pu}$ and/or ${ }^{240} \mathrm{Pu}$ content of $>10 \%$ can be considered sufficient to denaturate the plutonium for military application. Although ${ }^{239} \mathrm{Pu} \%$ is $\sim 96$ in all cases after an operation period of 6 months, it decreases 78-85 depending on the fuel and coolant type at the end of the operation period. On the other hand, ${ }^{238} \mathrm{Pu}$ and/or ${ }^{240} \mathrm{Pu}$ content is $>10 \%$ in the investigated blanket in the case of all coolants and fuels after an operation time of 24 months (see figures 6-8). Hence, the plutonium component of the fuel can never reach a nuclear weapon grade quality at the end operation of the investigated blanket.

\section{Discussion and conclusions}

The main conclusions of this study can be given as below.

- Innovative coolants, Flinabe and $\mathrm{Li}_{20} \mathrm{Sn}_{80}$ show good performance, especially on taking into consideration fissile fuel breeding and CFFE with maintaining sufficient tritium for 


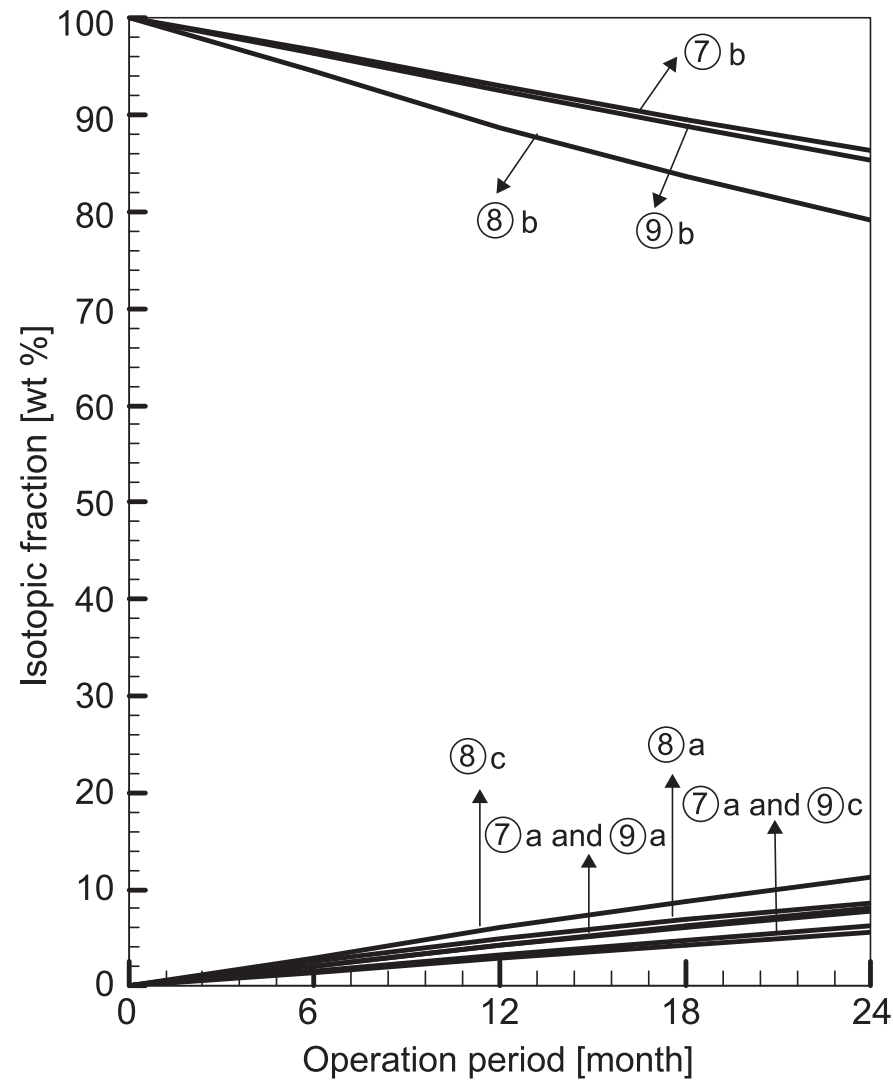

Figure 8. Temporal variation in the percentages of the plutonium isotopes ((a) ${ }^{238} \mathrm{Pu}$; (b) ${ }^{239} \mathrm{Pu}$; (c) ${ }^{240} \mathrm{Pu}$ ) for the fuel $\mathrm{UN}$ with (7) natural lithium, (8) Flinabe, (9) $\mathrm{Li}_{20} \mathrm{Sn}_{80}$.

the (DT) driver. Natural lithium absorbs more neutrons for tritium breeding than either Flinabe or $\mathrm{Li}_{20} \mathrm{Sn}_{80}$ and thus affects fissile fuel breeding and fission in the negative direction.

- Investigated blankets with UC or UN having similar results show higher neutronic performance than those with $\mathrm{UO}_{2}$, due to the fact that $\mathrm{UO}_{2}$ has the lowest uranium density among the fuels used in this study.

- Using high NWL $\left(10 \mathrm{MW} / \mathrm{m}^{2}\right)$ allows increasing burnup grades of the fuel and therefore decreases the net fissile fuel production. Its important advantage is the attainment of high CFFE values more rapidly. Hence, LWR grade fuel rods can be produced in a shorter time for charging when compared to previous studies using an NWL of $<10 \mathrm{MW} / \mathrm{m}^{2}$ at the first wall of the blanket (Şahin et al 1998; Yapıcıet al 1999; Yapıcı\& Özceyhan 2000).

\section{References}

Abdou M A 1999 On the exploration of innovative concepts for fusion chamber technology. APEX Interim Report (Overview), UCLA-ENG-99-206, UCLA-FNT-107, University of California, Los Angeles, CA

Berwald D H et al 1982 Fission Suppressed Hybrid Reactor Fusion Breeder, Lawrence Livermore National Laboratory, UCID-19327 
Bettis E S, Robertson R C 1970 Design and performance features of a single-fluid molten salt breeder reactor. Nucl. Appl. Tech. 8: 190-207

Greene N M 1997 BONAMI, resonance self-shielding by the bondarenko method, NUREG/CR-0200, Revision 5, 2, section F1, ORNL/NUREG/CSD-2/V2/R5, Oak Ridge National Laboratory, Oak Ridge, TN

Greene N M, Petrie L M 1997 XSDRNPM, A one-dimensional discrete-ordinates code for transport analysis. NUREG/CR-0200, Revision 5, 2, Section F3, ORNL/NUREG/CSD-2/V2/R5, Oak Ridge National Laboratory

Greene N M, Petrie L M, Westfall R M 1997 NITAWL-II, Scale system module for performing resonance shielding and working library production. NUREG/CR-0200, Revision 5, 2, Section F2, ORNL/NUREG/CSD-2/V2/R5, Oak Ridge National Laboratory

Grimes W R, Cantor S 1972 Molten salt as blanket fluids in controlled fusion reactors. In The chemistry of fusion technology (New York: Plenum)

Greenspan E 1984 Fusion-fission hybrid reactors. Advances in science and technology (eds) J Lewins, M Becker (New York: Plenum) 16: 289

Jaeger R G, Blizard E P, Chilton A B, Grotenhuis M, Hönig A Th, Jaeger A, Eisenlohr H H 1968 Shielding fundamentals and methods. Engineering compendium on radiation shielding, I (Berlin: Springer-Verlag)

Jordan W C, Bowman S M 1997 Scale cross-section libraries. NUREG/CR-0200, Revision 5, 3, section M4, ORNL/NUREG/CSD-2/V3/R5, Oak Ridge National Laboratory, Oak Ridge, TN

Landers N F, Petrie L M 1997 CSAS, Control module for enhanced criticality safety analysis sequences. NUREG/CR-0200, Revision 5, 1, section C4, ORNL/NUREG/CSD-2/V1/R5, Oak Ridge National Laboratory

Lee J D et al 1982 Feasibility Study of a Fission-Suppressed Tandem-Mirror Hybrid Reactor Fusion Breeder, Lawrence Livermore National Laboratory, CA, UCID-19327

Malinauskas A P, Richardson D M 1974 The solubilities of hydrogen, deuterium and helium in molten LiF-BeF 2 . Ind. Eng. Chem. Fundam. 13: 242-252

Meyer W, Loyalka S K, Nelson W E, Williams R W 1977 The homemade nuclear bomb syndrome. Nuclear Safety 18: 427

Moir R W 1982 The fusion breeder. Submitted to the National Science Foundation Policy Workshop, Washington DC, March 4-5, Lawrence Livermore Laboratory, CA, UCRL-87290

Moriyama H, Sagara A, Tanaka S, Moir R W, Sze D K 1998 Molten salts in fusion nuclear technology. Fusion Eng. Design 39-40: 627-637

Moriyama H, Tanaka S, Sze D K, Reimann J, Terlain A 1995 Tritium recovery from liquid metals. Fusion Eng. Design 28: 226-239

Raghep M H et al 1979 Nuclear performance of molten salt fusion-fission symbiotic system for catalyzed D-D and D-T reactors. ORNL-TM-6560, Oak Ridge National Laboratory, Oak Ridge, TN

Şahin S 1980 Reply to the remarks on the plutonium-240 induced preignition problem in a nuclear device, Nucl. Technol. 54: 431-432

Şahin S 1982 Addendum to "Reply to remarks on the plutonium-240 induced pre-ignition problem in a nuclear device." Nucl. Technol. 58: 354

Şahin S 1990 Power flattening in a catalysed deuterium-deuterium fusion-driven hybrid blanket using nuclear waste actinides. Nucl. Technol. 92, 93-105

Şahin S 1991 Radiation shielding calculations for fast reactors. Gazi University, Publication \# 169, Faculty of Science and Literature, Publication number 22, Ankara, Turkey (in Turkish)

Şahin S, Al-Kusayer T 1985 Conceptual design studies of a cylindrical experimental $\mathrm{ThO}_{2}$ blanket with (D,D) driver. Kerntechnik 47: 259-266

Şahin S, Ligou J 1980 The effect of the spontaneous fission of plutonium-240 on the energy release in a nuclear explosive. Nucl. Technol. 50: 88-94

Şahin S, Übeyli M 2004a Modified apex reactor as a fusion breeder. Energy Conver. Manage. 45: 1497-1512 
Şahin S, Übeyli M 2004b LWR Spent fuel transmutation in a high power density fusion reactor. Ann. Nucl. Energy 31: 871-890

Şahin S, YapıcıH 1989 Investigation of the neutronic potential of moderated and fast (D,T) hybrid blankets for rejuvenation of CANDU spent fuel. Fusion Technol. 16: 331-345

Şahin S, Yapıc1H 1998 Rejuvenation of LWR fuel in fusion blankets. Ann. Nucl. Energy 25: 1317-1339

Şahin S, YapıcıH 1999a Neutronic analysis of a thorium fusion breeder with enhanced protection against nuclear weapon proliferation. Ann. Nucl. Energy 26: 13-27

Şahin S, Al-Kusayer T A, Raoof M A 1986 Preliminary design studies of a cylindrical experimental hybrid blanket with deuterium-tritium driver. Fusion Technol. 10: 84-99

Şahin S, YapıcıH, Baltacıoğlu E, Al-Kusayer T A 1991a A hybrid reactor design concept driven by cold $(\mathrm{D}, \mathrm{T})$ fusion neutrons and fueled with metallic thorium. Int. J. Energy-Environ.-Econ. 1: 167-173

Şahin S, Baltacıoğlu E, YapıcıH 1991b Potential of a catalysed fusion-driven hybrid reactor for the regeneration of CANDU spent fuel. Fusion Technol. 20: 26-39

Şahin S, YapıcıH, Baltacıoğlu E 1994 Rejuvenation of LWR spent fuel in a catalyzed fusion hybrid blanket. Kerntechnik, 59: 270-277

Şahin S, YapıcıH, Baltacıoğlu E 1998 Fusion breeder with enhanced safeguarding capabilities against nuclear weapon proliferation. Energy Conver. Manage. 39: 899-909

Şahin S, YapıcıH, Bayrak M 1999 Spent mixed oxide fuel rejuvenation in fusion breeders. Fusion Eng. Design 47: 9-23

Şahin S, Özceyhan V, YapıcıH 2001a Proliferation hardening and power flattening of a thorium fusion breeder with triple mixed oxide fuel. Ann. Nucl. Energy 28: 203-223

Şahin S, YapıcıH, Şahin N 2001b Neutronic performance of proliferation hardened thorium fusion breeders. Fusion Eng. Design 54: 63-77

Şahin S, Yalçın Ş, Şahin H M, Übeyli M 2003a Neutronics analysis of HYLIFE-II blanket for fissile fuel breeding in an inertial fusion energy reactor. Ann. Nucl. Energy 30: 669-683

Şahin S, Yalçın Ş, Şahin H M, Übeyli M 2003b Neutronic Investigation of a hybrid version of the ARIES-RS fusion reactor. Ann. Nucl. Energy 30: 245-59

Smith D L et al 1985 Blanket comparison and selection study. Fusion Technol. 8: 10-44

Smid I, Akiba M, Vieider G, Plöchl L 1998 Development of tungsten armor and bonding to copper for plasma-interactive components. J. Nucl. Mater. 258-263: 160-172

Sze D K, Moir R W, Zinkle S 1999 Database for liquid breeders and coolants. On the exploration of innovative concepts for fusion chamber technology (ed.) M Abdou, APEX Interim Report (Overview), UCLA-ENG-99-206, UCLA-FNT-107, University of California, Los Angeles, CA

Übeyli M 2003 On the tritium breeding capability of Flibe, Flinabe and $\mathrm{Li}_{20} \mathrm{Sn}_{80}$ in a fusion-fission (hybrid) reactor. J. Fusion Energy 22: 51-57

Übeyli M 2004 Transmutation of minor actinides discharged from LMFBR spent fuel in a high power density fusion reactor. Energy Convers. Manage. (in press)

YapiciH et al 1999 Potential of a fusion-fission hybrid reactor using uranium for various coolants to breed fissile fuel for LWRs. Ann. Nucl. Energy 26: 821-823

YapıcıH, Özceyhan V 2000 Numerical neutronic analysis of a natural lithium cooled fusion breeder fueled with $\mathrm{UO}_{2}$, Arabian J. Sci. Eng. 25(2A): 95-109

YapıcıH, Übeyli M, Yalçın Ş 2002 Neutronic analysis of Prometheus reactor fueled with various compounds of thorium and uranium. Ann. Nucl. Energy 29: 1871-1889

YapıcıH, Ýpek O, Übeyli M 2003 Investigation of the performance parameters and temperature distribution in fuel rod dependent on operation periods and first wall loads in fusion-fission reactor system fueled with $\mathrm{ThO}_{2}$. Energy Conver. Manage. 44: 573-595

YapıcıH, Übeyli M 2003 Power Flattening in Prometheus breeder reactor using nuclear fuel and waste actinide. Ann. Nucl. Energy 30: 159-173

Youssef M Z, Sawan M E, Sze D K 2002 The breeding potential of 'flinabe' and comparison to 'flibe' in 'CLiFF' high power density concept. Fusion Eng. Design 61-62: 497-503

Zinkle S J, Ghoniem N M 2000 Operating temperature windows for fusion reactor structural materials. Fusion Eng. Design 51-52: 55-71 